\title{
Article \\ Characterization of Particle Emissions from a DGEN 380 Small Turbofan Fueled with ATJ Blends
}

\author{
Remigiusz Jasiński $^{1}\left(\mathbb{D}\right.$, Paula Kurzawska ${ }^{1, *(\mathbb{D})}$ and Radosław Przysowa ${ }^{2}$ (D) \\ 1 Faculty of Civil and Transport Engineering, Poznan University of Technology, 60-965 Poznan, Poland; \\ remigiusz.jasinski@put.poznan.pl \\ 2 Instytut Techniczny Wojsk Lotniczych (ITWL), ul. Ksiecia Boleslawa 6, 01-494 Warsaw, Poland; \\ radoslaw.przysowa@itwl.pl \\ * Correspondence: paula.kurzawska@put.poznan.pl
}

Citation: Jasiński, R.; Kurzawska, P.; Przysowa, R. Characterization of Particle Emissions from a DGEN 380 Small Turbofan Fueled with ATJ Blends. Energies 2021, 14, 3368. https://doi.org/10.3390/en14123368

Academic Editor: Jesper Schramm

Received: 27 April 2021

Accepted: 3 June 2021

Published: 8 June 2021

Publisher's Note: MDPI stays neutral with regard to jurisdictional claims in published maps and institutional affiliations.

Copyright: (c) 2021 by the authors. Licensee MDPI, Basel, Switzerland. This article is an open access article distributed under the terms and conditions of the Creative Commons Attribution (CC BY) license (https:// creativecommons.org/licenses/by/ $4.0 /)$.

\begin{abstract}
The fine particulate matter (PM) emitted from jet aircraft poses a serious threat to the environment and human health which can be mitigated by using biofuels. This paper aims to quantify PM emissions from a small turbofan fueled with the alcohol to jet (ATJ) synthetic kerosene and its various blends (5\%, 20\%, and 30\% of ATJ) with Jet A-1 fuel. Emissions from a turbofan engine (DGEN 380) with a high bypass ratio, applicable in small private jets, were studied. Among the four fuels tested, the PM-number emission index $\left(\mathrm{EI}_{\mathrm{N}}\right)$ was the lowest for the ATJ $30 \%$ blend. $\mathrm{EI}_{\mathrm{N}}$ for ATJ $30 \%$ dropped from $1.1 \times 10^{17}$ to $4.7 \times 10^{16}$ particles $/ \mathrm{kg}$ of fuel. Burning alternative fuel blends reduced the particle mass emissions over the entire range of fuel flow by at least $117 \mathrm{mg} / \mathrm{kg}$ of fuel. The particles formed in the nucleation mechanism dominate PM emission, which is characteristic of jet engines. Thus, number-based particle size distributions (PSDs) exhibit a single mode log-normal distribution. The highest values of $\mathrm{EI}_{\mathrm{N}}$ were found for Jet A-1 neat compared to other fuels. The use of the ATJ additive did not cause significant changes in the size of the particles from nucleation mode. However, a magnitude reduction of nucleation mode was found with the increase in the ATJ ratio.
\end{abstract}

Keywords: alcohol-to-jet; alternative fuel; emission; particles; particulate matter

\section{Introduction}

In recent years, interest in reducing the environmental impact of aviation has increased significantly, especially because of climate change and environmental pollution. Currently, the aviation industry is responsible for an estimated $2 \%$ of global greenhouse gas emissions [1,2]. This has motivated research for alternative aviation propulsion and sustainable aviation fuels [3,4]. Focusing only on gaseous harmful compounds emitted by aircraft engines is insufficient to fully address the environmental impact of aviation. It is also crucial to reduce particulate matter emissions, which can affect the growth and life-time of the contrails for example. In particular, particles containing sulfur and black carbon can act as nucleation centers for ice crystal formation. In turn, the simultaneous occurrence of contrails and cirrus clouds affect the heating of the earth's surface and thus global warming $[5,6]$. On the other hand, particulate matter have significant impact on air pollution and thus on human health. Particles from aircraft engines are small enough to penetrate the respiratory system. Inhalable particles can cause, among other things, cardiovascular and respiratory diseases $[7,8]$. The vast majority of aviation emissions are generated at high altitudes, however, the regional aspect should be kept in mind. The health aspect of airport employees and people living in its the vicinity is important. The conventional approach exhaust emissions from aircraft engines assumes its control during the take-off, climbing, landing, and taxiing phases of the aircraft. The considered air operations, which are the subject of analyses of the impact of air transport on air quality, take place at altitudes of up to $950 \mathrm{~m}(3000 \mathrm{ft})$. This is evidenced by the regulations for the certification of aircraft engines, designed to limit exhaust emissions in areas adjacent to airports [9-12]. 
Although much research has already been done focusing on particulate emissions from aircraft engines, research into the emissions of non-volatile particulate matter (nvPM) in particular is still necessary. Regulatory limits for mass and number-based nvPM emissions will become applicable from 2023 [13]. Several projects have been developed focusing on particulate matter from aircraft engines, e.g., Research of Aviation PM Technologies, mOdelling and Regulation (RAPTOR) [14]; and AVIATOR-Assessing aViation emission Impact on local Air quality at airports: Towards Regulation [15]. RAPTOR focuses on, i.e., providing enhanced insights into PM including the ultrafine PM (UFP) component within aircraft exhaust emissions [14]. In turn, one of the goals of the AVIATOR is to measure emission from aircraft engine fueled with alternative fuel to find its impact on particulate matter formation in the plume but also locally, in the airport environment [15].

Biofuels are known to produce less particulate matter than conventional fuels, so they can contribute to reducing PM emissions in aviation [16-21]. Using a blend of biofuel and conventional fuel in aircraft engine can decrease the number and mass of emitted particles immediately behind the aircraft by $50-70 \%$ comparing to pure conventional fuel [18]. Since 2009 there are seven methods of producing alternative aviation fuels approved by the ASTM D7566 standard, which is a standard assigned for aviation turbine fuel containing synthesized hydrocarbons (Table 1) [22,23]. Bio-jet fuels are produced from, i.e., vegetable oil, lignocellosic biomass, algae, and municipal solid wastes. Aviation fuels must meet a number of requirements to be used in aircraft engines, mainly for safety reasons. Primarily biofuels should meet physicochemical properties described in the standard ASTM D7566, but also many environmental and operational requirements, like compatibility with the existing fuel infrastructure and reduction of greenhouse gas emission [22,24].

Table 1. Methods of producing alternative fuels approved by the ASTM D7566 standard $[22,23,25]$.

\begin{tabular}{|c|c|c|c|c|}
\hline Abbreviation & Process & Raw Material & Approval Date & Blending Limit \\
\hline FT-SPK & $\begin{array}{l}\text { Fischer-Tropsch Synthetic } \\
\text { Paraffinic Kerosene }\end{array}$ & $\begin{array}{c}\text { Biomass (wood waste, grass, } \\
\text { municipal solid waste), } \\
\text { natural gas }\end{array}$ & 2009 & up to $50 \%$ \\
\hline HEFA-SPK & $\begin{array}{l}\text { Hydroprocessed Esters and } \\
\text { Fatty Acids }\end{array}$ & $\begin{array}{l}\text { Oily biomass, e.g., algae, } \\
\text { jatropha, camelina, lipids }\end{array}$ & 2011 & up to $50 \%$ \\
\hline HFS-SIP & $\begin{array}{l}\text { Hydroprocessed Fermented } \\
\text { Sugars to Synthetic Isoparaffins }\end{array}$ & $\begin{array}{l}\text { Bacterial conversion of sugars } \\
\text { into hydrocarbons }\end{array}$ & 2014 & up to $10 \%$ \\
\hline FT-SPK/A & FT-SPK with aromatics & $\begin{array}{l}\text { Renewable biomass, i.e., } \\
\text { municipal solid waste, } \\
\text { agricultural and wood waste }\end{array}$ & 2015 & up to $50 \%$ \\
\hline ATJ-SPK & $\begin{array}{c}\text { Alcohol-to-Jet Synthetic } \\
\text { Paraffinic Kerosene }\end{array}$ & $\begin{array}{l}\text { Agricultural waste (corn shoots, } \\
\text { grass, straw), cellulosic biomass, }\end{array}$ & 2016 & up to $50 \%$ \\
\hline $\mathrm{CH}-\mathrm{SKK}$ or $\mathrm{CHJ}$ & $\begin{array}{l}\text { Catalytic Hydrothermolysis } \\
\text { Synthesized Kerosene }\end{array}$ & $\begin{array}{l}\text { vegetable or animal fats, oils } \\
\text { and greases }\end{array}$ & 2020 & up to $50 \%$ \\
\hline $\begin{array}{l}\text { HHC-SPK or } \\
\text { HC-HEFA-SPK }\end{array}$ & $\begin{array}{l}\text { Hydroprocessed Hydrocarbons, } \\
\text { Esters and Fatty Acids } \\
\text { Synthetic Paraffinic Kerosene }\end{array}$ & $\begin{array}{c}\text { Hydrocarbons of biological } \\
\text { origin, fatty acid esters, free fatty } \\
\text { acids, or a species of Botryococcus } \\
\text { braunia algae }\end{array}$ & 2020 & up to $10 \%$ \\
\hline
\end{tabular}

One of the technology process approved by ASTM D7566 in 2016 is Alcohol-to-Jet Synthetic Paraffinic Kerosene (ATJ-SPK), which allows to blend ATJ-SPK with conventional fuel up to $50 \mathrm{vol} \%$. The production of Alcohol to Jet (ATJ) can be divided in two main processes: production of the alcohol and conversion of the alcohol to jet fuel. Raw material for ATJ fuel is for example agricultural waste-like corn shoots, straw, and grass-but also cellulosic biomass. Raw material is subjected to the process of alcohol synthesis, and the product is alcohol with the chain length of $2-5$ carbon atoms [22,26]. Currently, only ethanol and iso-butanol are allowed by ASTM D7566 norm. One of the main biotechnological production process for alcohol is fermentation of sugar by yeasts, but there is also a fermentation process developed by LanzaTech Ltd. (Skokie, IL, USA), which is based on 
carbon reach gases produced for example by steel mills $[27,28]$. The next steps of alcohol to jet process are: alcohol dehydration, oligomerization, hydrogenation, and fractionation (Figure 1) [26,29].
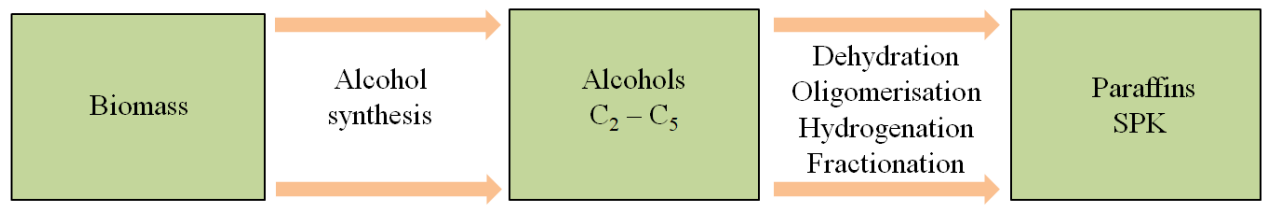

Figure 1. Diagram of the ATJ-SPK process [26].

Since the approval of the ATJ-SPK process in 2016, only a few tests for particulate matter emission have been performed on ATJ fuel [30-32], while other authorized aviation biofuel production technologies are tested much more frequently, for example HEFA-SPK and FT-SPK [30]. The research was carried out on an engine that is used in private jets, which extends the results of research carried out on communication aviation engines. The goal of this study is to analyze PM emissions from a small turbofan fuelled with the blends of ATJ and Jet A-1. For this purpose, particle mass and number distributions are related to fuel flow and related to those from the neat Jet A-1 fuel. What is more, particle size distributions, both for particle number and volume emission indexes are presented to study the impact of ATJ on particle formation. The experimental data of PM emissions of ATJ-derived fuels, can be used for various engineering research and technical-economic analysis.

\section{Materials and Methods}

\subsection{Test Engine, Fuels, Operating Schedule}

The propellants used during this research were the conventional Jet A-1 fuel and Alcohol-to-jet Synthetic Paraffinic Kerosene produced from isobutanol. Before the test, the alternative fuel was mixed in the following volume proportions with the JetA-1 fuel: $0 \%$ ATJ, 5\% ATJ, 20\% ATJ, and 30\% ATJ. The physicochemical properties of these fuel blends were presented by Przysowa et al. [23].

The DGEN 380 turbofan has been tested for gaseous emission [33-35] but not for particulate matter yet. The DGEN 380 turbofan was tested in the engine test cell located in ITWL using the data acquisition system and engine control system developed by price induction. General view of the test station is presented in Figure 2. Fuel tank and boost pump were located under the control room. The engine tests were carried out during a single day.

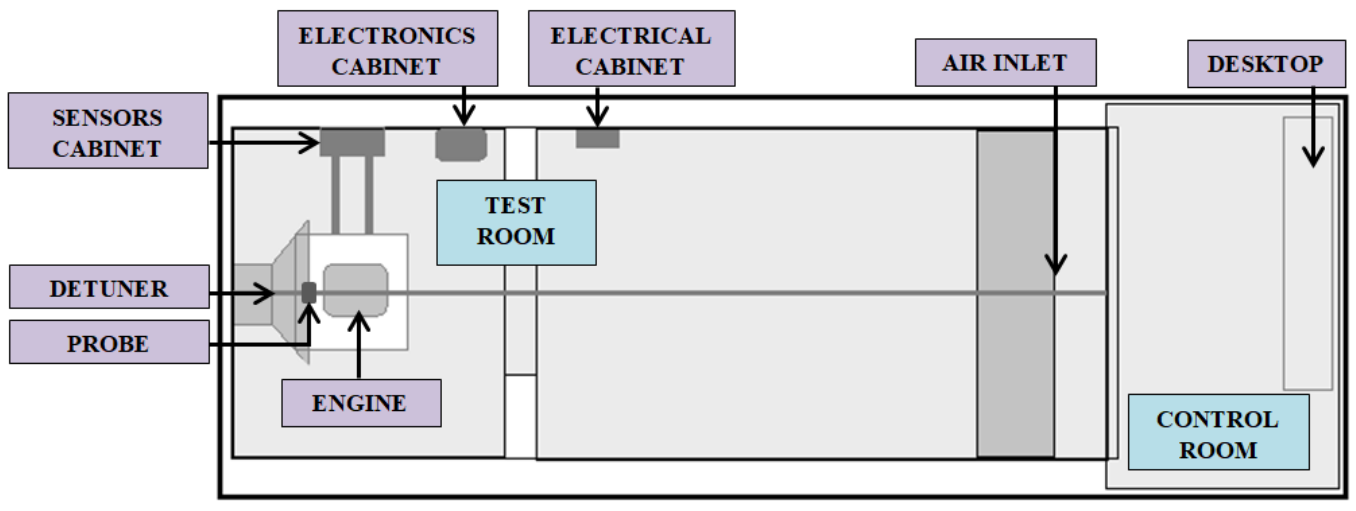

Figure 2. Scheme of the engine test cell [36].

DGEN 380 is a two-spool unmixed flow turbofan with a high bypass ratio equal 7.6. It has six modules: (1) axial fan module, (2) gearbox module with a planetary gearbox, (3) low pressure (LP) module with a radial compressor, (4) high pressure (HP) module 
with an embedded starter-generator, (5) central module hosting the fan and HP rotor, (6) combustion and primary exhaust module with the annular combustion chamber, as well as the oil and fuel control unit. The engine core consists of a radial compressor and two axial turbines. The planetary gearbox with reduction ratio of 3.32 connects the low pressure (LP) spool and the fan. Basic information about the tested engine is presented in Table $2[36,37]$.

Table 2. Technical specification of the DGEN 380 turbofan [36].

\begin{tabular}{cc}
\hline Parameter & Value \\
\hline Maximum Thrust & $255 \mathrm{daN}$ \\
Specific Fuel Consumption (for maximum thrust) & $12.4 \mathrm{~g} / \mathrm{kN} \cdot \mathrm{s}$ \\
Bypass ratio & 7.6 \\
Weight & $85 \mathrm{~kg}$ \\
Lifetime & $3600 \mathrm{~h}$ \\
\hline
\end{tabular}

The engine tests started with Jet A-1 aviation fuel (treated as the reference fuel). In subsequent runs, blends of Jet A-1 with ATJ-SPK biofuel in increasing concentration were used. Tests were carried out under specific ambient conditions: temperature $18-22.5^{\circ} \mathrm{C}$, atmospheric pressure $1000.1 \mathrm{hPa}$.

Table 3 presents the test matrix with the selected engine operating points and obtained temperatures of exhaust gas samples. The measurements started with a preliminary test run to warm up the engine and check proper operation of the engine and equipment. The engine test for each fuel blend was the same and consisted of eight thrust settings. Exhaust gas sampling took place for approximately $180 \mathrm{~s}$ for each value of thrust.

Table 3. Engine test matrix.

\begin{tabular}{ccccc}
\hline Test Number & $\begin{array}{c}\text { Fuel } \\
\text { Type }\end{array}$ & $\begin{array}{c}\text { Average Sample } \\
\text { Gas Temperature } \\
\left({ }^{\circ} \mathbf{C}\right)\end{array}$ & $\begin{array}{c}\text { Fuel Flow Rate } \\
\mathbf{( 1 / h )}\end{array}$ & $\begin{array}{c}\text { Tested Percent Rated } \\
\text { Thrust Settings } \\
(\%)\end{array}$ \\
\hline 1-pretest, warm & ATJ 0\% & $15.4 \pm 0.1$ & $32,37,49,66,86,151 \pm 1.5$ & $10,15,25,40,55,100 \pm 2 \%$ value \\
2 & ATJ 0\% & $15.9 \pm 0.1$ & $32,37,44,49,66,86,112,151 \pm 1.5$ & $10,15,20,25,40,55,70,100 \pm 2 \%$ value \\
3 & ATJ 5\% & $16.1 \pm 0.1$ & $33,36,44,49,68,87,111,148 \pm 1.5$ & $10,15,20,25,40,55,70,100 \pm 2 \%$ value \\
4 & ATJ 20\% & $15.8 \pm 0.1$ & $33,37,45,50,70,87,111,148$ & $10,15,20,25,40,55,70,100 \pm 2 \%$ value \\
5 & ATJ 20\% & $15.8 \pm 0.1$ & $33,37,45,50,70,87,111,148$ & $10,15,20,25,40,55,70,100 \pm 2 \%$ value \\
6 & ATJ 30\% & $15.9 \pm 0.1$ & $33,36,44,50,69,87,112,148 \pm 1.5$ & $10,15,20,25,40,55,70,100 \pm 2 \%$ value \\
7 & ATJ 30\% & $15.9 \pm 0.1$ & $33,36,44,50,69,87,112,148 \pm 1.5$ & $10,15,20,25,40,55,70,100 \pm 2 \%$ value \\
\hline
\end{tabular}

\subsection{Apparatus and Procedures}

Selected online instrumentation was mounted in a $3 \mathrm{~m}$ long sampling system to measure particle size distribution (PSD), carbon dioxide $\left(\mathrm{CO}_{2}\right)$, carbon monoxide (CO), hydrocarbons $(\mathrm{HC})$, and sample gas temperature in the sampling tunnel.

The sampling probe was made of stainless steel which is non-reactive in high temperature. Cyclone was used in accordance with ICAO recommendations. The cyclone functions by removing large particles, preventing counting errors, and keeping the instrument clean. The cyclone removes large particles and fibers that can cause excessive noise on one or more channels and are not the effect of jet engine operation.

Measurement of particle size distribution was performed with TSI 3090 EEPS (Engine Exhaust Particle Sizer). It enabled the measurement of a discrete range of particle diameters $(5.6-560 \mathrm{~nm})$ on the basis of their differing speeds. The degree of the electric mobility of particulate matter is changed exponentially, and measurement of their size is carried out at a frequency of $10 \mathrm{~Hz}$.

Semtech DS analyzer was used to measure gaseous exhaust compounds. An exhaust gas analyzer used in this research allowed for the measurement of the concentration of 
$\mathrm{CO}, \mathrm{CO}_{2}$, and $\mathrm{HC}$. The exhaust gases were introduced to the analyzer via a cable, whose temperature was $191{ }^{\circ} \mathrm{C}$ which was required to measure the hydrocarbon concentration in the flame-ionization analyzer. In the next stage-after cooling the flue gas to $4{ }^{\circ} \mathrm{C}$ - the measurements of the concentration of carbon monoxide and carbon dioxide took place.

\subsection{Data Analyses}

The data acquired with TSI 3090 EEPS provided particle number concentrations and particle size distribution of the emissions from the tested engine. The differential number particle size distribution, $\mathrm{dCN} / \mathrm{d} \log \mathrm{Dp}$, at a specified fuel flow rate (and thrust) was obtained by averaging the particle numbers recorded under the same engine operating condition from the same instrument particle size bins. The PM mass emissions were calculated by converting the PM number concentration data measured by the EEPS into the PM mass concentrations assuming unit density [38]. The particles are considered as spheres and the density is equally distributed according to certain model. The density change curve was taken into account, which was determined empirically for particulates from an aircraft jet engine. The particle number and mass concentrations were averaged and then used to calculate the emission index $\left(\mathrm{EI}_{\mathrm{N}}, \mathrm{EI}_{\mathrm{V}}, \mathrm{EI}_{\mathrm{M}}\right)$ for the given pollutant and test parameters.

\section{Results}

\subsection{Particle Number Emission Indices}

The average $\mathrm{PM}$ number emission indices $\left(\mathrm{EI}_{\mathrm{N}}\right)$ and their associated error bars were calculated from the EEPS data as provided in Figure 3 for the different test fuels. The average $\mathrm{EI}_{\mathrm{N}}$ decreasing from $2.2 \times 10^{17}$ to $9.9 \times 10^{16}$ particles per kilogram of Jet A- 1 fuel as the engine fuel flow increased from 26 to $89 \mathrm{~kg} / \mathrm{h}$. Along with the increase in fuel flow to the value of $118 \mathrm{~kg} / \mathrm{h}$, a slight increase in the $\mathrm{EI}_{\mathrm{N}}$ to the value $1.2 \times 10^{17}$ particles $/ \mathrm{kg}$ was observed. The Figure also shows that, in comparison to the other fuels tested, Jet A-1 had the highest $\mathrm{EI}_{\mathrm{N}}$ values over the entire range of engine thrust (fuel flow rate). The values of $\mathrm{EI}_{\mathrm{N}}$ for the ATJ $30 \%$ were the lowest among the four fuels tested. The $\mathrm{EI}_{\mathrm{N}}$ for $\mathrm{ATJ} 30 \%$ dropped from $1.1 \times 10^{17}$ to $4.7 \times 10^{16}$ particles $/ \mathrm{kg}$ of fuel when the fuel flow rate increased from 26 to $55 \mathrm{~kg} / \mathrm{h}$. Further increase in thrust (fuel flow rate) resulted in an increase in the $\mathrm{EI}_{\mathrm{N}}$ for all tested fuels, for ATJ $30 \%$ to the value of $1.1 \times 10^{17}$ particles $/ \mathrm{kg}$ of fuel. Thus, the $\mathrm{EI}_{\mathrm{N}}$ function takes a U-shaped curve with the emissions high at idle, dropping off to a minimum at mid-range power, and rising again at high fuel flow rate. This relationship was confirmed in the case of other publications on particulate matter emissions from jet engines $[20,39]$. As expected, the $\mathrm{EI}_{\mathrm{N}}$ values for the blends of ATJ $5 \%$ and ATJ $20 \%$ with Jet A-1 fell between the Jet A-1 and ATJ 30\%, showing similar trend.

\subsection{PM Mass Emission Indices}

The PM mass emission indices $\left(\mathrm{EI}_{\mathrm{M}}\right)$ under various test conditions were calculated from the EEPS measurements. Figure 4 shows the effect of fuel blend and its flow rate (and thrust) on the $\mathrm{EI}_{\mathrm{M}}$. Burning alternative blends fuels reduced the particle mass emissions over the entire range of fuel flow rates observed (except $120 \mathrm{~kg} / \mathrm{h}$ fuel flow rate for ATJ $30 \%$ which will be discussed later on). At low fuel flow rates, $\mathrm{EI}_{\mathrm{M}}$ decreased substantially as the fuel flow rate increased, with the minimum $117 \mathrm{mg} / \mathrm{kg}$ fuel reached at a fuel flow rate of $89 \mathrm{~kg} / \mathrm{h}$. The reduction of $\mathrm{EI}_{\mathrm{M}}$ significantly decreased to the value of fuel flow rate equal to $40 \mathrm{~kg} / \mathrm{h}$, above this value the $\mathrm{EI}_{\mathrm{M}}$ remained constant or slightly increased. The higher concentration of the alternative fuel resulted in a more effective particle mass emission reduction. The reason for the increase in $\mathrm{EI}_{\mathrm{M}}$ at high fuel flow rates is most likely an increase in the particles emission of larger diameters in the soot mode [40-42]. Even a small number of particles with diameters greater than $50 \mathrm{~nm}$ significantly affects the mass emission, especially in the case of jet engines where particles with diameters less than $20 \mathrm{~nm}$ (nucleation mode) dominate. A detailed particle size distribution analysis is presented below. 


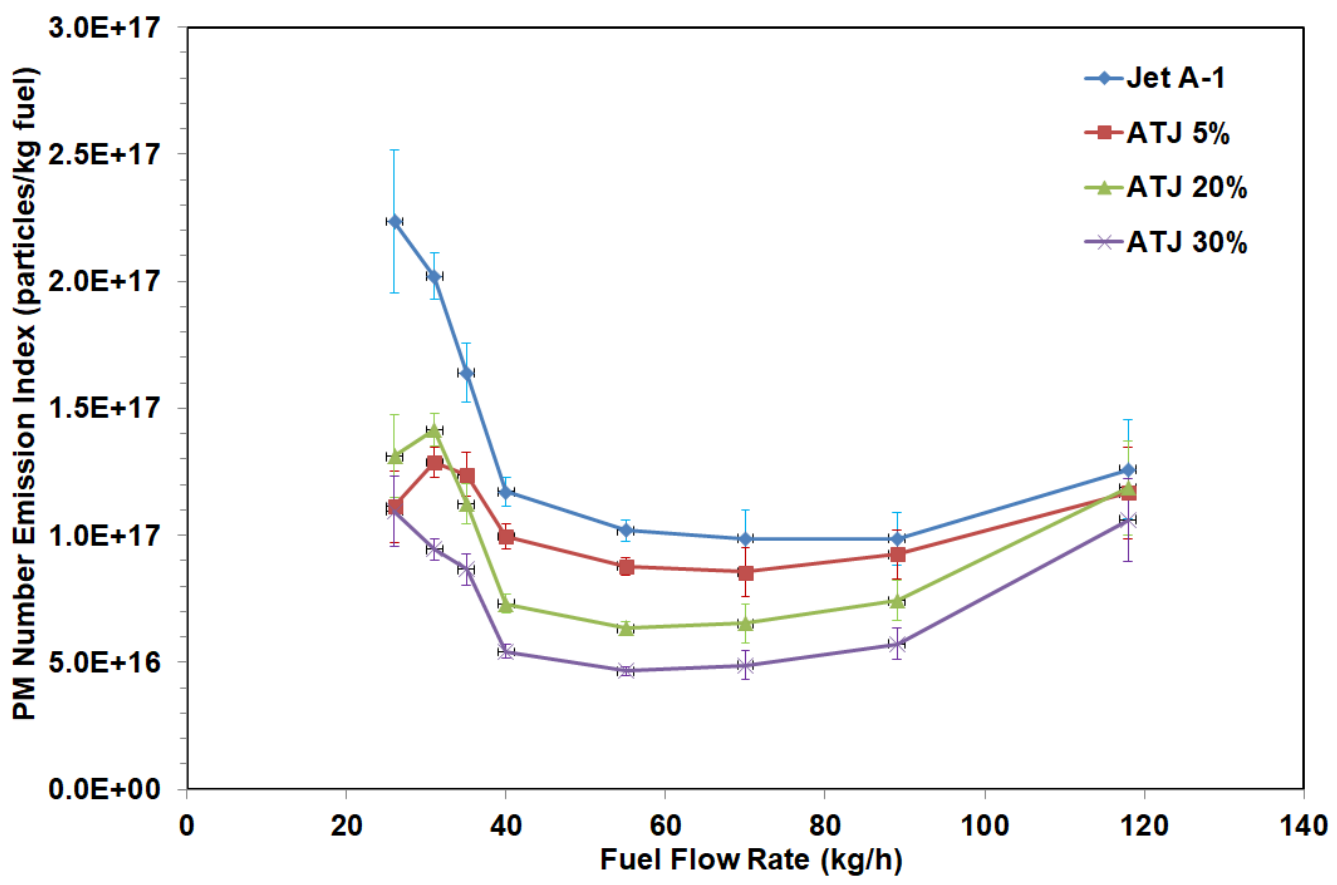

Figure 3. Particle number emissions index $\left(\mathrm{EI}_{\mathrm{N}}\right)$ versus DGEN 380 fuel flow. Error bars represent single standard deviation.

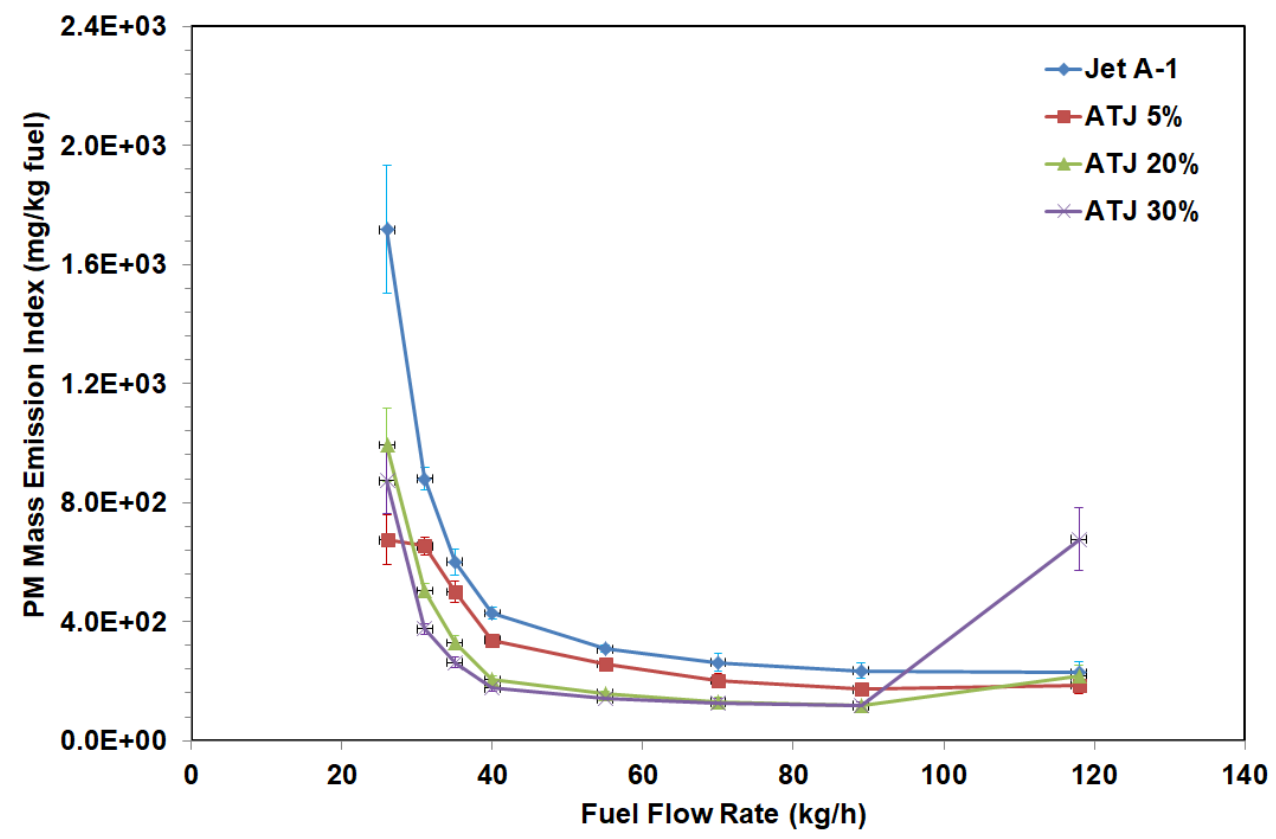

Figure 4. PM mass emission index $\left(\mathrm{EI}_{\mathrm{M}}\right)$ versus DGEN 380 fuel flow. Error bars represent one standard deviation.

\subsection{Particle Size Distribution}

The data recorded by the EEPS was averaged for the same fuel flow rate settings and then converted to differential number-based $\left(\mathrm{dEI}_{\mathrm{N}} / \mathrm{d} \log \mathrm{D}_{\mathrm{p}}\right)$ and differential volume-based $\left(\mathrm{dEI}_{\mathrm{V}} / \mathrm{d} \log \mathrm{D}_{\mathrm{p}}\right)$ particle size distributions. Figure 5 represents example plots of $\mathrm{dEI}_{\mathrm{N}} / \mathrm{d}$ $\log \mathrm{D}_{\mathrm{p}}$ and $\mathrm{dEI}_{\mathrm{V}} / \mathrm{d} \log \mathrm{D}_{\mathrm{p}}$ under different fuel flow rate (additionally thrust is indicated) for DGEN 380 while burning Jet A-1 (Figure 5a,b), ATJ 5\%/Jet A-1 blend (Figure 5c,d), ATJ 20\%/Jet A-1 blend (Figure 5e,f), and ATJ 30\%/Jet A-1 blend (Figure 5g,h). The particles formed in the nucleation mechanism dominate PM emission, which is characteristic of jet engines. Thus, number-based PSDs exhibit a single mode log-normal distribution. PSDs 
based on the number of particles indicate that particles with diameters greater than $100 \mathrm{~nm}$ are practically non-existent. Increasing the fuel flow rate results in the formation of particles in a soot mode due to coagulation and condensation of sulfur and aromatic hydrocarbons. A small number of particles with diameters greater than $30 \mathrm{~nm}$ and $100 \mathrm{~nm}$ are formed, resulting in bimodal or even trimodal PSDs in some cases (Figure $5 b, \mathrm{~d}, \mathrm{f}, \mathrm{h}$ ).

The center of the nucleation mode peaks showed relatively minor changes with thrust for the number PSDs. Their magnitude mostly decreased as thrust increased. In some cases $(70 \%$ and $100 \%$ thrust in particular) the increases of magnitude were observed in nucleation mode peaks. The center of the soot mode peaks does not change significantly with increasing fuel flow rate. However, changes in the soot mode value caused by increasing engine thrust can be seen. As thrust increases, the magnitude of soot mode peaks mostly increases.

Fuel composition effects on the PSD can also be observed in Figure 5 for the four fuels. The highest values of $\mathrm{EI}_{\mathrm{N}}$ were found for Jet A-1 neat compared to other fuels. The use of the ATJ additive did not cause significant changes in the size of the particles from nucleation mode. However, a magnitude reduction of nucleation mode was found with the increase in the share of ATJ. This was seen in particular for ATJ 30\% where the average reduction was about $50 \%$. Other fuels were ranked in this respect between the Jet A-1 neat and ATJ $30 \%$.

The relative magnitude of the $\mathrm{EI}_{\mathrm{V}}$ in soot mode was the highest for Jet A-1 neat. The addition of ATJ resulted in a reduction of magnitude of soot and nucleation mode. In the case of the $30 \%$ ATJ fuel, there is an upward trend for the soot mode, which indicates that particles larger than $560 \mathrm{~nm}$ could be produced.

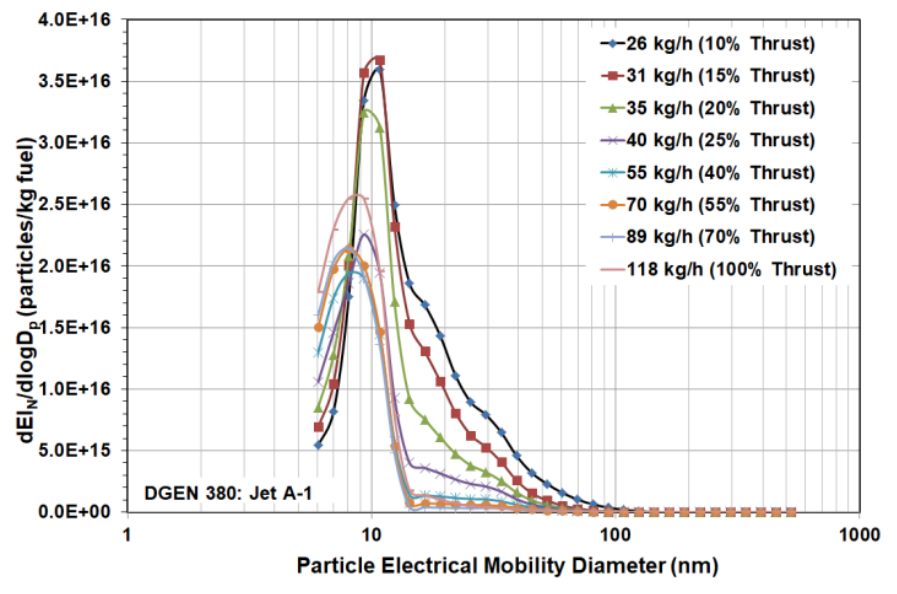

(a) EIN PSD for Jet A-1

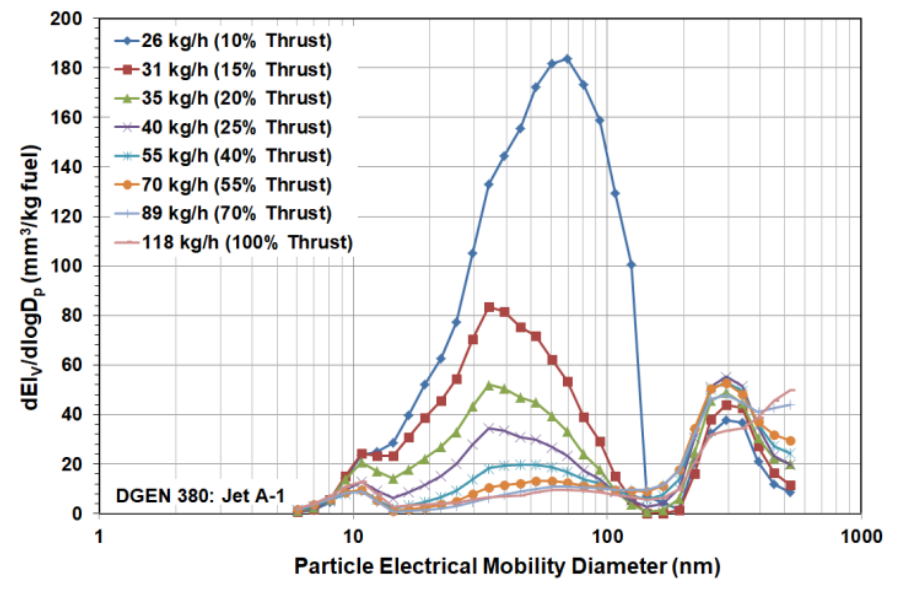

(b) EIv PSD for Jet A-1

Figure 5. Cont. 


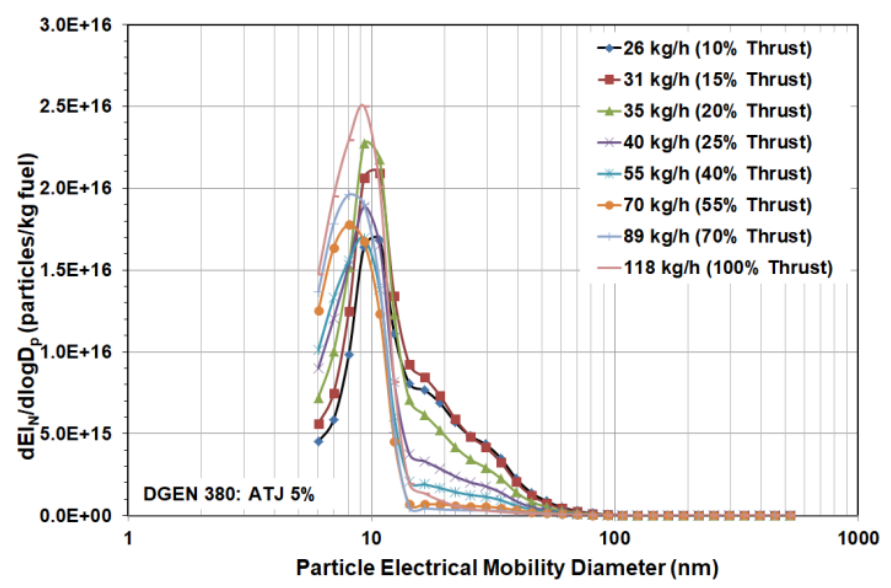

(c) EIN PSD for ATJ 5\%/Jet A-1 blend

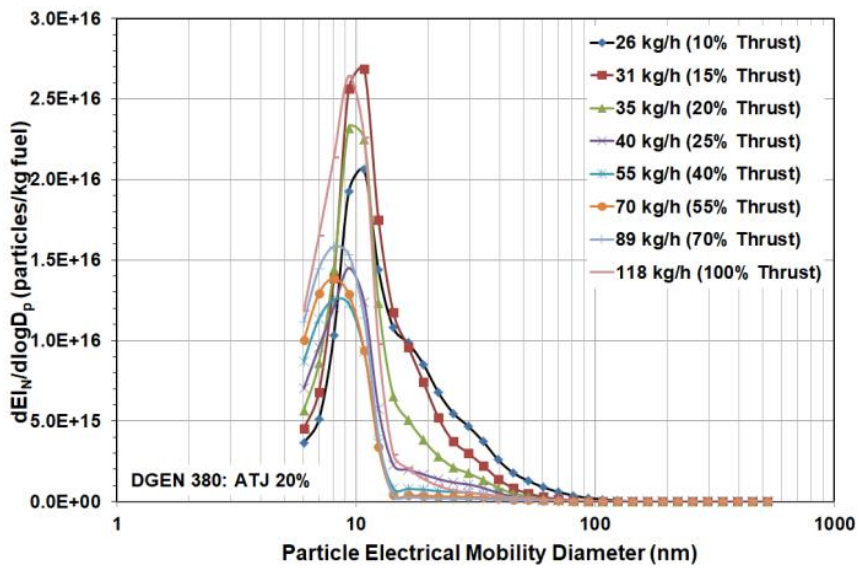

(e) EIN PSD for ATJ 20\%/Jet A-1 blend

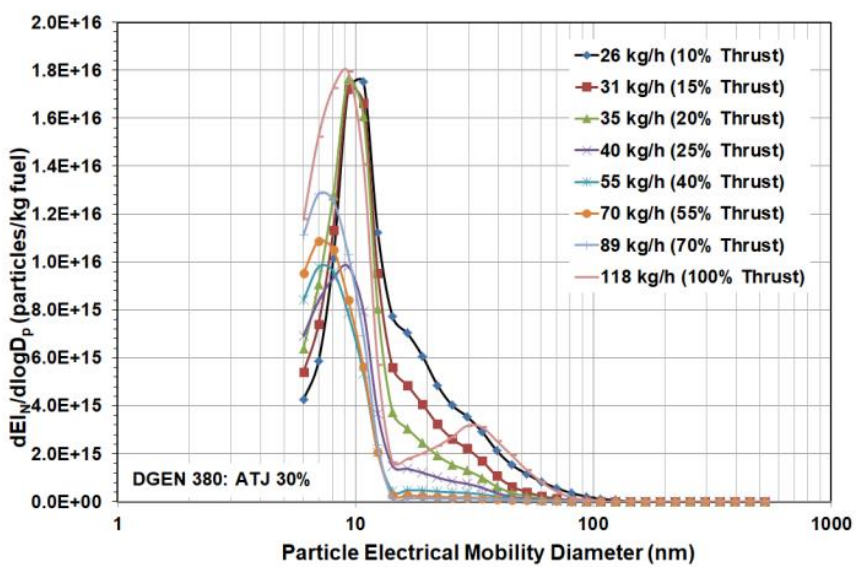

(g) EIN PSD for ATJ 30\%/Jet A-1 blend

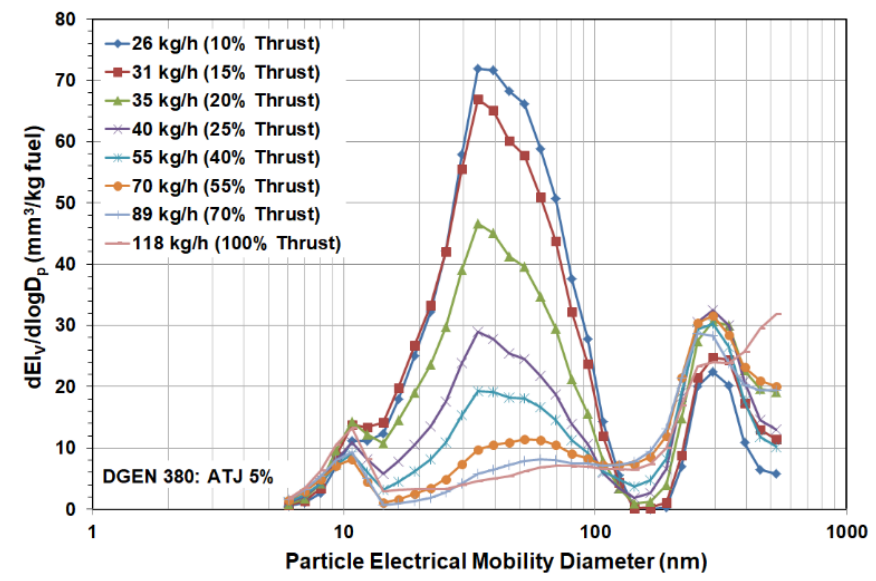

(d) EIv PSD for ATJ 5\%/Jet A-1 blend

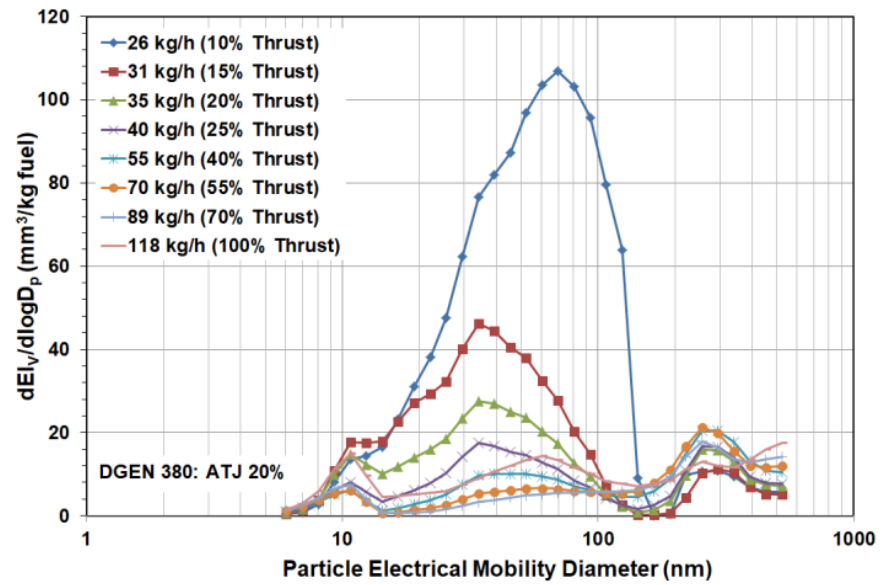

(f) EIv PSD for ATJ 20\%/Jet A-1 blend

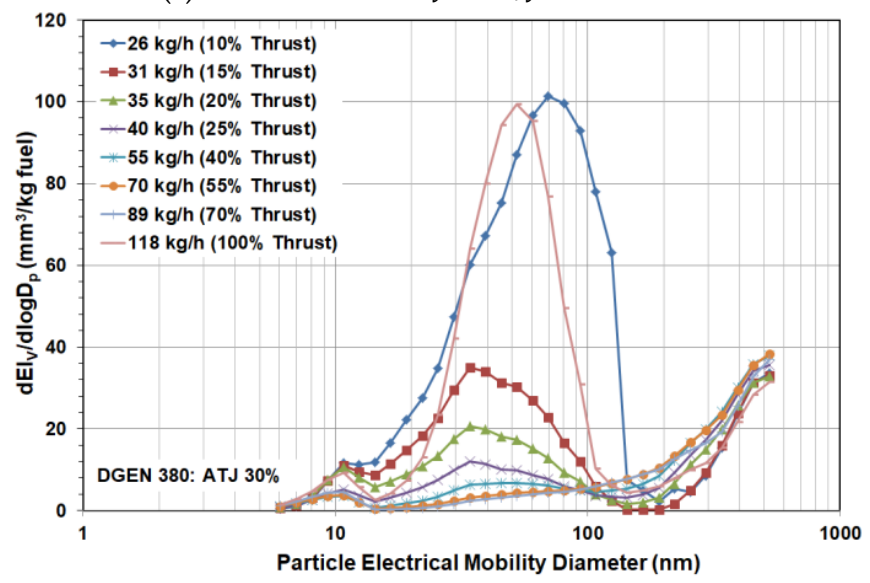

(h) EIv PSD for ATJ 30\%/Jet A-1 blend

Figure 5. Differential particle number emission index $\left(\mathrm{EI}_{\mathrm{N}}\right)$ and differential particle volume emission index (EIV) PSDs for DGEN 380 burning Jet A-1 (a,b), ATJ5\%/Jet A-1 blend (c,d), ATJ20\%/Jet A-1 blend (e,f) and ATJ30\%/Jet A-1 blend (g,h). Engine operating point is expressed as both fuel flow and percent rated thrust.

\section{Discussion}

The presented data show that the use of the biocomponent reduces PM emissions. In order to determine the magnitude change for both $\mathrm{EI}_{\mathrm{N}}$ and $\mathrm{EI}_{\mathrm{M}}$, the average percentage change was determined relative to the Jet A- 1 fuel as shown in Figure 6. The median values for each fuel type as determined across all engine thrust levels were also calculated. As shown in Figure 6, the amount of reduction depends both on the share of the biocomponent and the engine's thrust. 


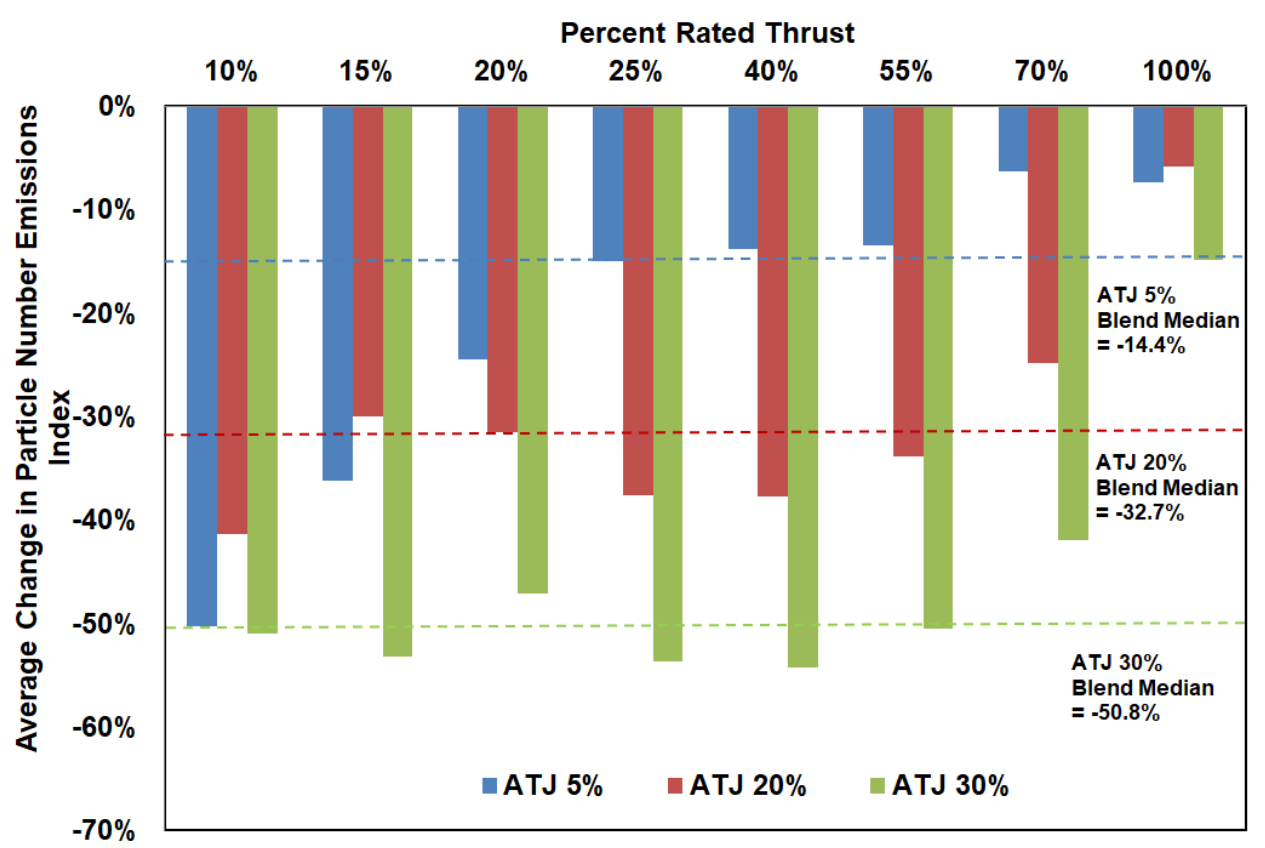

(a)

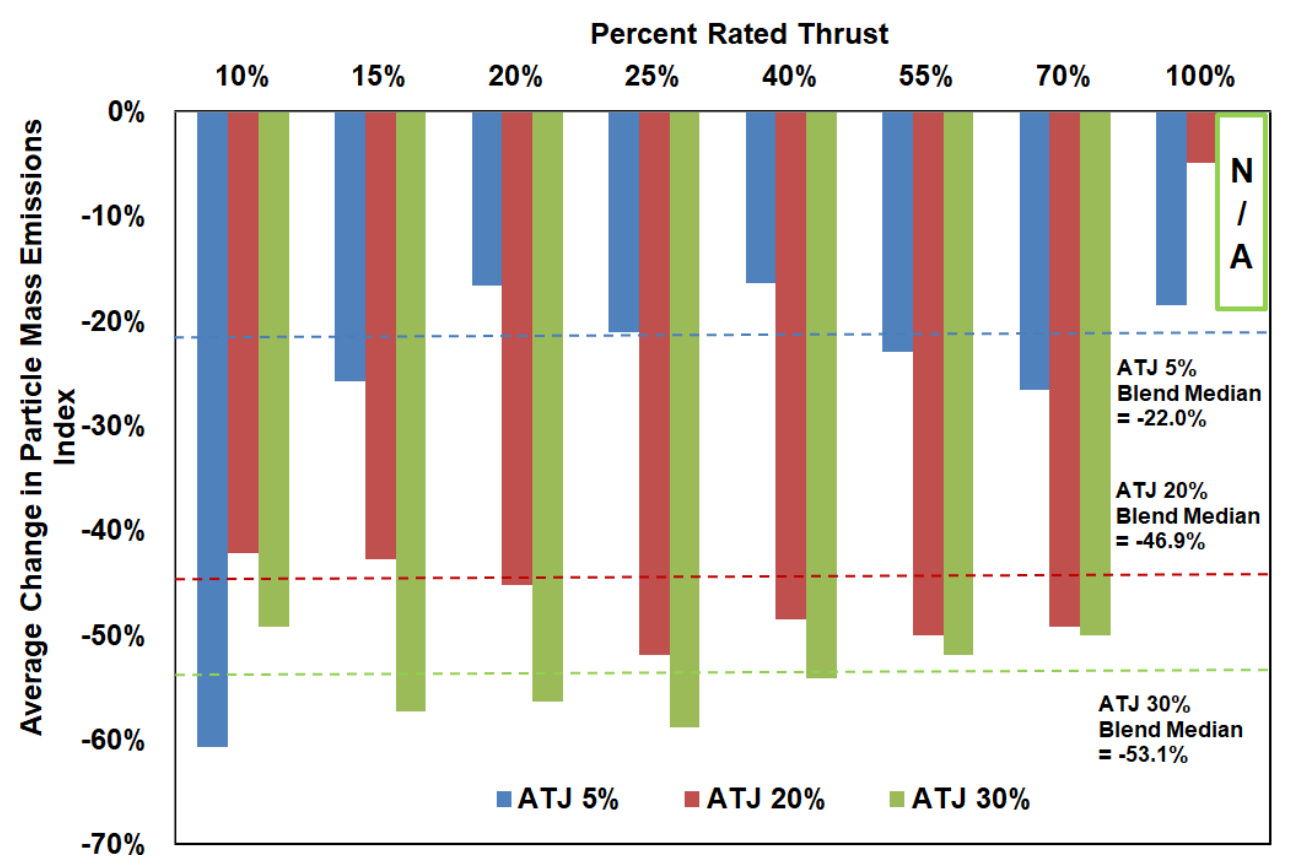

(b)

Figure 6. Average change in emissions index relative to Jet A-1 at different engine thrust for (a) particle number and $(\mathbf{b})$ particle mass emissions. Also shown are the median values for each data set.

For the particle number index, the reduction ranged from $6 \%$ to $54 \%$ for the three blends. The associated median values across the entire thrust range for $\mathrm{EI}_{\mathrm{N}}$ were $14 \%, 33 \%$, $51 \%$ for ATJ 5\%, ATJ 20\%, and ATJ 30\%, respectively. The reductions of $\mathrm{EI}_{\mathrm{M}}$ varied from $5 \%$ to $61 \%$ for the tested fuels. The determined reduction was also dependent on the value of the thrust force. The median reduction in $\mathrm{EI}_{\mathrm{M}}$ were $22 \%, 47 \%$, and $53 \%$ for ATJ $5 \%$, ATJ $20 \%$, and ATJ 30\%, respectively.

Kinsey et al. [20] showed that the use of alternative fuels may result in a linear decrease in the $\mathrm{EI}_{\mathrm{N}}$ over the entire operating range of the engine. In the case of higher thrust values, it is associated with lower emission of the volatile fraction of particles precursors (lower 
sulfur and aromatic content) [20]. In the case of the presented results, only the non-volatile fraction is analyzed.

Figure 6 does not show the $\mathrm{EI}_{\mathrm{M}}$ reduction for the ATJ 30\% fuel at $100 \%$ thrust. The reason is the increase in $\mathrm{EI}_{\mathrm{M}}$ resulting from the clearly bimodal PSD seen in Figure $5 \mathrm{~g}$. Clearly high concentration of particles with a diameter of $\sim 50 \mathrm{~nm}$ can be seen. This resulted in a large increase in the generated mass, which in turn is not justified in the literature. There are many factors that could have caused the situation, including an uncontrolled change in the engine operation.

Based on Figure 6, it can be concluded that the reduction in the number and mass of particles increases with growing share of ATJ. The above-mentioned relationship is reported $[31,43,44]$. The change of the non-volatile $\mathrm{EI}_{\mathrm{N}}$ and $\mathrm{EI}_{\mathrm{M}}$ is related to the reduction of the sulfur content and the aromatic compounds in blend. Aromatics contained in the engine oil, which also cause formation of volatile particles, should be taken into account [45]. In addition, it should be considered that increasing the proportion of hydrogen in the fuel also reduces the formation of particulate matter in the soot mode. Reducing the share of aromatics results in an increase in the $\mathrm{H} / \mathrm{C}$ ratio, therefore it is difficult to say what influences the PM emission to a greater extent $[30,46,47]$.

Research shows that in the case of burning pure alternative fuels, soot formation is drastically reduced $[20,44]$. The effect on soot formation depends on the alternative fuel used, and so, for example, ATJ has higher sooting tendency, which can be attributed to its higher average molecular weight in comparison to FT-SPK and HEFA [44].

Due to the large reduction of the emission of non-volatile solid particles, it is important to take into account the solid particles formed after mixing exhaust gas with air [44]. Conducting this type of test requires taking a sample at a certain distance from the engine exhaust nozzle (e.g., $30 \mathrm{~m}$ ) and usually from the engine mounted in the airplane. The obtained results often differ due to the adopted testing methodology, in particular the selected engine. The research also shows that in the analysis of the results, in addition to the PM loss correction model (in the case of a long measuring path), the temperature of the sample should be taken into account [20].

\section{Conclusions}

Particulate matter emissions were measured with the use of ATJ fuel and its various blends with Jet A-1 fuel. The research was carried out on a turbine engine with a high bypass ratio, applicable in very light jets which are small private jets. The tests were carried out in the entire range of engine thrust, concentration of particles, and all other values necessary to determine the emission indexes $\left(\mathrm{EI}_{\mathrm{N}}, \mathrm{EI}_{\mathrm{M}}, \mathrm{EI}_{\mathrm{V}}\right)$.

The particle size distribution in terms of their number, regardless of the fuel used, assumed the lognormal shape. The use of the ATJ fuel additive resulted in a decrease in its magnitude (the greater the share of ATJ, the greater the decrease). It was found that the use of ATJ fuel as an additive to Jet A-1 reduces the formation of particulate matter in the soot mode, which is mainly attributed to a reduction in the concentration of sulfur and aromatic hydrocarbons in the fuel.

The directions of further work include the assessment of the impact of fuel composition on the formation of the volatile particles and the analysis of black carbon content (BC).

On the basis of the obtained results, it can be stated that it is advantageous to use ATJ fuel in air transport in the highest concentrations. Studies have shown that increasing the share of ATJ gives the greatest ecological benefits. ATJ fuel has been approved for use since 2016 in a share of up to $50 \%$ of aviation fuel.

Author Contributions: Conceptualization, R.J. and R.P.; Data curation, R.J.; Formal analysis, P.K.; Funding acquisition, R.J.; Investigation, P.K.; Methodology, R.J.; Project administration, R.J.; Resources, R.P.; Software, P.K.; Supervision, R.P.; Validation, R.J., P.K., and R.P.; Visualization, R.J.; Writing-original draft, R.J.; Writing—review and editing, P.K. All authors have read and agreed to the published version of the manuscript. 
Funding: The APC was funded by Interdisciplinary Rector's Grant, grant number ERP/33/32/ SIGR/0004.

Acknowledgments: Our special thanks are extended to Aleksander Olejnik from the Military University of Technology in Warsaw for providing the DGEN 380 turbofan and Anna Mikołajczyk for performing engine tests. We also wish to thank Jacek Pielecha from the Poznań University of Technology for his contribution to emission measurements and substantive support, and Bartosz Gawron and Tomasz Białecki from ITWL for their guidance on used fuels and engine testing methodology.

Conflicts of Interest: The authors declare no conflict of interest.

\section{References}

1. IRENA. Biofuels for Aviation, Technology Brief; International Renewable Energy Agency: Abu Dhabi, United Arab Emirates, 2017.

2. Bosch, J.; Hoefnagels, R.; Jong, S.; Slade, R. Aviation Biofuels: Strategically Important, Technically Achievable, Tough to Deliver; Grantham Institute, Imperial College London: London, UK, 2017.

3. Starck, L.; Pidol, L.; Jeuland, N.; Chapus, T.; Bogers, P.; Bauldreay, J. Production of Hydroprocessed Esters and Fatty Acids (HEFA)-Optimisation of Process Yield. Oil Gas Sci. Technol. Rev. de l'IFP 2014, 71. [CrossRef]

4. Capaz, R.S.; de Medeiros, E.M.; Falco, D.G.; Seabra, J.E.; Osseweijer, P.; Posada, J.A. Environmental trade-offs of renewable jet fuels in Brazil: Beyond the carbon footprint. Sci. Total Environ. 2020, 714, 136696. [CrossRef] [PubMed]

5. Chen, L.; Gao, K.; Zhang, C.; Lang, W. Alternative fuels for IC engines and jet engines and comparison of their gaseous and particulate matter emissions. In Advanced Biofuels; Woodhead Publishing: Sawston, UK, 2019; pp. 17-64.

6. Burkhardt, U.; Kärcher, B. Global radiative forcing from contrail cirrus. Nat. Clim. Chang. 2011, 1, 54-58. [CrossRef]

7. Jasinski, R. Estimation of particles emissions from a jet engine in real flight. E3S Web Conf. 2019, 100, 00029. [CrossRef]

8. World Health Organization. Health Effects of Particulate Matter. Policy Implications for Countries in Eastern Europe; Caucasus and Central Asia; World Health Organization: Geneva, Switzerland, 2013. Available online: https://www.euro.who.int/_data/ assets / pdf_file/0006/189051/Health-effects-of-particulate-matter-final-Eng.pdf (accessed on 9 April 2021).

9. Lee, D.; Pitari, G.; Grewe, V.; Gierens, K.; Penner, J.; Petzold, A.; Prather, M.; Schumann, U.; Bais, A.; Berntsen, T. Transport impacts on atmosphere and climate: Aviation. Atmos. Environ. 2010, 44, 4678-4734. [CrossRef]

10. Yim, S.H.L.; Lee, G.L.; Lee, I.H.; Allroggen, F.; Ashok, A.; Caiazzo, F.; Eastham, S.D.; Malina, R.; Barrett, S.R.H. Global, regional and local health impacts of civil aviation emissions. Environ. Res. Lett. 2015, 10, 34001. [CrossRef]

11. Burnett, R.; Chen, H.; Szyszkowicz, M.; Fann, N.; Hubbell, B.; Pope, C.A.; Apte, J.S.; Brauer, M.; Cohen, A.; Weichenthal, S.; et al Global estimates of mortality associated with long-term exposure to outdoor fine particulate matter. Proc. Natl. Acad. Sci. USA 2018, 115, 9592-9597. [CrossRef]

12. Quadros, F.D.A.; Snellen, M.; Dedoussi, I.C. Regional sensitivities of air quality and human health impacts to aviation emissions. Environ. Res. Lett. 2020, 15, 105013. [CrossRef]

13. Lobo, P.; Durdina, L.; Brem, B.T.; Crayford, A.P.; Johnson, M.P.; Smallwood, G.J.; Siegerist, F.; Williams, P.I.; Black, E.A.; Llamedo, A.; et al. Comparison of standardized sampling and measurement reference systems for aircraft engine non-volatile particulate matter emissions. J. Aerosol Sci. 2020, 145, 105557. [CrossRef]

14. European Comission. Research of Aviation PM Technologies, Modelling and Regulation. Available online: https://cordis.europa. eu/project/id/863969 (accessed on 26 April 2021).

15. Archilla, V.; Hormigo, D.; Sánchez-García, M.; Raper, D. AVIATOR-Assessing aViation emission Impact on local Air quality at airports: TOwards Regulation. MATEC Web Conf. 2019, 304, 02023. [CrossRef]

16. Moore, R.H.; Shook, M.; Beyersdorf, A.; Corr, C.; Herndon, S.; Knighton, W.B.; Miake-Lye, R.; Thornhill, K.L.; Winstead, E.L.; Yu, Z.; et al. Influence of Jet Fuel Composition on Aircraft Engine Emissions: A Synthesis of Aerosol Emissions Data from the NASA APEX, AAFEX, and ACCESS Missions. Energy Fuels 2015, 29, 2591-2600. [CrossRef]

17. Brem, B.T.; Durdina, L.; Siegerist, F.; Beyerle, P.; Bruderer, K.; Rindlisbacher, T.; Rocci-Denis, S.; Andac, M.G.; Zelina, J.; Penanhoat, O.; et al. Effects of Fuel Aromatic Content on Nonvolatile Particulate Emissions of an In-Production Aircraft Gas Turbine. Environ. Sci. Technol. 2015, 49, 13149-13157. [CrossRef]

18. Moore, R.H.; Thornhill, K.L.; Weinzierl, B.; Sauer, D.; D'Ascoli, E.; Kim, J.; Lichtenstern, M.; Scheibe, M.; Beaton, B.; Beyersdorf, A.J.; et al. Biofuel blending reduces particle emissions from aircraft engines at cruise conditions. Nat. Cell Biol. 2017, 543, 411-415. [CrossRef]

19. Lobo, P.; Condevaux, J.; Yu, Z.; Kuhlmann, J.; Hagen, D.E.; Miake-Lye, R.C.; Whitefield, P.D.; Raper, D.W. Demonstration of a Regulatory Method for Aircraft Engine Nonvolatile PM Emissions Measurements with Conventional and Isoparaffinic Kerosene fuels. Energy Fuels 2016, 30, 7770-7777. [CrossRef]

20. Kinsey, J.S.; Squier, W.; Timko, M.T.; Dong, Y.; Logan, R. Characterization of the Fine Particle Emissions from the Use of Two Fischer-Tropsch Fuels in a CFM56-2C1 Commercial Aircraft Engine. Energy Fuels 2019, 33, 8821-8834. [CrossRef]

21. Jürgens, S.; Oßwald, P.; Selinsek, M.; Piermartini, P.; Schwab, J.; Pfeifer, P.; Bauder, U.; Ruoff, S.; Rauch, B.; Köhler, M. Assessment of combustion properties of non-hydroprocessed Fischer-Tropsch fuels for aviation. Fuel Process. Technol. 2019, 193, 232-243. [CrossRef] 
22. Kurzawska, P.; Jasiński, R. Overview of Sustainable Aviation Fuels with Emission Characteristic and Particles Emission of the Turbine Engine Fueled ATJ Blends with Different Percentages of ATJ Fuel. Energies 2021, 14, 1858. [CrossRef]

23. Przysowa, R.; Gawron, B.; Białecki, T.; Łegowik, A.; Merkisz, J.; Jasiński, R. Performance and Emissions of a Microturbine and Turbofan Powered by Alternative Fuels. Aerospace 2021, 8, 25. [CrossRef]

24. ICAO. Sustainable Aviation Fuels Guide; International Civil Aviation Organization: Montreal, QC, Canada, 2018.

25. Chiaramonti, D. Sustainable Aviation Fuels: The challenge of decarbonization. Energy Procedia 2019, 158, 1202-1207. [CrossRef]

26. Zschocke, A.; Scheuermann, S.; Ortner, J. High Biofuel Blends in Aviation (HBBA), ENER/C2/2012/420-1, Final Report; Lufthansa: Cologne, Germany, 2012.

27. Richter, S.; Braun-Unkhoff, M.; Naumann, C.; Riedel, U. Paths to alternative fuels for aviation. CEAS Aeronaut. J. 2018, 9, 389-403. [CrossRef]

28. Burton, F. LanzaTech is Recognized as an Industry Leader in Bending the Carbon Curve. LanzaTech. Available online: https: / / www.lanzatech.com/2021/04/23/lanzatech-is-recognized-as-an-industry-leader-in-bending-the-carbon-curve/ (accessed on 9 April 2021).

29. Wang, W.-C.; Tao, L. Bio-jet fuel conversion technologies. Renew. Sustain. Energy Rev. 2016, 53, 801-822. [CrossRef]

30. Tran, S.; Brown, A.; Olfert, J.S. Comparison of Particle Number Emissions from In-Flight Aircraft Fueled with Jet A1, JP-5 and an Alcohol-to-Jet Fuel Blend. Energy Fuels 2020, 34, 7218-7222. [CrossRef]

31. Xue, X.; Hui, X.; Singh, P.; Sung, C.-J. Soot formation in non-premixed counterflow flames of conventional and alternative jet fuels. Fuel 2017, 210, 343-351. [CrossRef]

32. Schripp, T.; Grein, T.; Zinsmeister, J.; Oßwald, P.; Köhler, M.; Müller-Langer, F.; Hauschild, S.; Marquardt, C.; Scheuermann, S.; Zschocke, A.; et al. Technical application of a ternary alternative jet fuel blend-Chemical characterization and impact on jet engine particle emission. Fuel 2021, 288, 119606. [CrossRef]

33. Pawlak, M.; Majka, A.; Kuzniar, M.; Pawluczy, J. MODEL OF EMISSION OF EXHAUST COMPOUNDS OF JET AIRCRAFT IN CRUISE PHASE ENABLING TRAJECTORY OPTIMIZATION. Transport 2020, 35, 87-97. [CrossRef]

34. Pawlak, M.; Kuźniar, M. Determination of CO2 Emissions for Selected Flight Parameters of a Business Jet Aircraft. J. Kones 2019, 26, 155-163. [CrossRef]

35. Gawron, B.; Białecki, T.; Janicka, A.; Suchocki, T. Combustion and Emissions Characteristics of the Turbine Engine Fueled with HEFA Blends from Different Feedstocks. Energies 2020, 13, 1277. [CrossRef]

36. DGEN 380 BR Training (Unpublished), Price Induction; Aviation Pros: Atlanta, GA, USA, 2017.

37. Berton, J.J. System Noise Prediction of the DGEN 380 Turbofan Engine. J. Aircr. 2016, 53, 1779-1786. [CrossRef]

38. Durdina, L.; Brem, B.; Abegglen, M.; Lobo, P.; Rindlisbacher, T.; Thomson, K.; Smallwood, G.; Hagen, D.; Sierau, B.; Wang, J. Determination of PM mass emissions from an aircraft turbine engine using particle effective density. Atmos. Environ. 2014, 99, 500-507. [CrossRef]

39. Kinsey, J.S.; Hays, M.D.; Dong, Y.; Williams, D.C.; Logan, R. Chemical Characterization of the Fine Particle Emissions from Commercial Aircraft Engines during the Aircraft Particle Emissions eXperiment (APEX) 1 to 3. Environ. Sci. Technol. 2011, 45, 3415-3421. [CrossRef]

40. Timko, M.T.; Fortner, E.; Franklin, J.; Yu, Z.; Wong, H.-W.; Onasch, T.B.; Miake-Lye, R.C.; Herndon, S.C. Atmospheric Measurements of the Physical Evolution of Aircraft Exhaust Plumes. Environ. Sci. Technol. 2013, 47, 3513-3520. [CrossRef] [PubMed]

41. Timko, M.T.; Onasch, T.B.; Northway, M.J.; Jayne, J.T.; Canagaratna, M.R.; Herndon, S.C.; Wood, E.C.; Miake-Lye, R.C.; Knighton, W.B. Gas Turbine Engine Emissions-Part II: Chemical Properties of Particulate Matter. J. Eng. Gas Turbines Power 2010, 132, 061505. [CrossRef]

42. Wong, H.-W.; Yelvington, P.E.; Timko, M.T.; Onasch, T.B.; Miake-Lye, R.C.; Zhang, J.; Waitz, I.A. Microphysical Modeling of Ground-Level Aircraft-Emitted Aerosol Formation: Roles of Sulfur-Containing Species. J. Propuls. Power 2008, $24,590-602$. [CrossRef]

43. Schripp, T.; Anderson, B.E.; Crosbie, E.C.; Moore, R.H.; Herrmann, F.; Oßwald, P.; Wahl, C.; Kapernaum, M.; Köhler, M.; Le Clercq, P.; et al. Impact of Alternative Jet Fuels on Engine Exhaust Composition During the 2015 ECLIF Ground-Based Measurements Campaign. Environ. Sci. Technol. 2018, 52, 4969-4978. [CrossRef] [PubMed]

44. Rojo, C.; Vancassel, X.; Mirabel, P.; Ponche, J.-L.; Garnier, F. Impact of alternative jet fuels on aircraft-induced aerosols. Fuel 2015, 144, 335-341. [CrossRef]

45. Jasiński, R.; Pielecha, J. Evaluation of the impact of oil presence in the aviation fuel on particle size distribution. Sci. J. Silesian Univ. Technol. Ser. Transp. 2017, 94, 57-64. [CrossRef]

46. Lobo, P.; Hagen, D.E.; Whitefield, P.D. Comparison of PM Emissions from a Commercial Jet Engine Burning Conventional, Biomass, and Fischer-Tropsch Fuels. Environ. Sci. Technol. 2011, 45, 10744-10749. [CrossRef]

47. Chan, T.W.; Canteenwalla, P.; Chishty, W.A. Characterization of Fuel Composition and Altitude Impact on Gaseous and Particle Emissions from a Turbojet Engine. In Proceedings of the ASME Turbo Expo 2017: Turbomachinery Technical Conference and Exposition, Charlotte, NC, USA, 26-30 June 2017; Volume 4A, p. 63131. [CrossRef] 